\title{
Discordant sex in one of three monozygotic triplets
}

\author{
B DALLAPICCOLA*, C STOMEO†, G FERRANTI*, A DI LECCE†, AND \\ M PURPURA $\ddagger$
}

From *the Department of Human Genetics, University of Urbino; the Department of Neonatology and Medical Genetics, Miulli Hospital, Acquaviva delle Fonti; and $¥$ the National Center of Blood Transfusion, Rome, Italy.

SUMMARY A case is reported of monozygotic triplets, discordant for phenotypic sex, in which the female presented at birth with the features of Turner's syndrome. Chromosomal analyses showed homogeneous 46,XY karyotypes in the lymphocytes of the three sibs, while a 45 , X non-mosaic chromosome constitution was detected in skin fibroblasts of the female triplet. It is suggested that mitotic non-disjunction or anaphase lag occurring early during embryonic development accounted for the occurrence of monosomy $X$ in one cell line of the affected triplet. Previous observations of monozygotic twin pairs discordant for chromosome constitutions are reviewed.

In 1961 Turpin et al ${ }^{1}$ reported a pair of monozygotic (MZ) twins of apparently opposite sex. The normal male had a $46, X Y$ karyotype, while the $45, X$ female displayed the typical features of Turner's syndrome. Since then, only a few additional cases of divergent chromosome constitutions in MZ twins have been recognised and the definition of monozygotic heterokaryotic twins (MZHT) is currently used to designate this condition.

An accident occurring during an early postzygotic cell division, before the laying down of the primitive streak, accounts for $\mathrm{MZ}$ heterokaryotic twinning, which results either in twins with identical phenotypic sex but different sex chromosome complement, or in twins with different phenotypic sex and sex chromosome complement, or even in twins with identical phenotypic sex but with a different clinical condition.

In general, the two cell populations are mixed in both the primitive streaks and the twins have mosaicism in different tissues. However, if the cell populations are homogeneous in the two primitive streaks, one of the twins is homogeneously normal, while the other is homogeneously abnormal. This latter situation is very uncommon, since varying degrees of blood intermixing usually occur in monozygosity owing to placental anastomoses. ${ }^{2}$

This report describes the first example to our knowledge of discordant sex in one of three $\mathrm{MZ}$ triplets.

Received for publication -10 April 1984 Accepted for publication 11 April 1984.

\section{Case reports}

The triplets were born in April 1983 after an uneventful 37 week pregnancy. The parents were both 35 years old at the time of delivery and they were healthy and unrelated. The triplets were the product of the mother's fourth pregnancy. Three previous children, two males and one female, were normal in all respects.

Triplet 1 was a girl who presented at birth with the typical features of Turner's syndrome. She had a webbed neck and swelling of the feet and hands (figure). Birth weight was $1980 \mathrm{~g}$, length $42 \mathrm{~cm}$, and head circumference $32 \mathrm{~cm}$. She did not cry immediately and was very pale. Apgar score was 2 after 1 minute, 6 after 5 minutes, and 8 after 10 minutes.

Triplets 2 and 3 were normal boys. Their birth weights were $2050 \mathrm{~g}$ and $2110 \mathrm{~g}$, respectively. They cried immediately. An Apgar of 10 was recorded after 1 minute.

The placenta was monochorionic and triamniotic. The placental membranes showed no abnormalities. No anastomoses were noticed in the placenta, but no histological study was done.

\section{DERMATOGLYPHS}

Dermatoglyphs were analysed by direct inspection of the hands. As expected for $\mathrm{MZ}$ triplets, the course of the main lines on the palms was similar. Axial triradii were proximally located. There were slight differences in the patterns of the fingertips involving the second fingers and the left fifth finger of triplet 1 (table 1). Although not carefully 


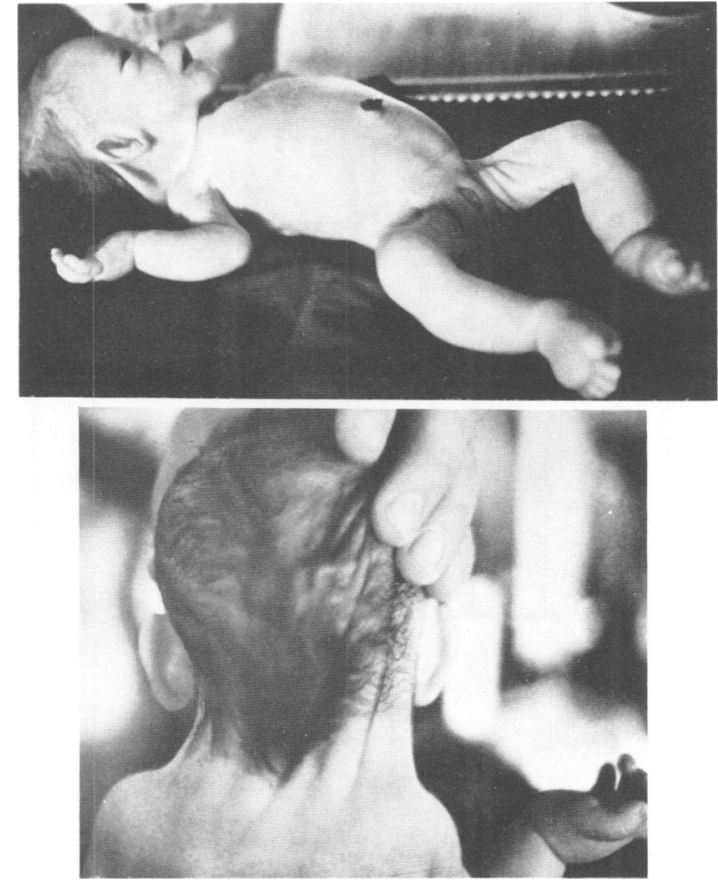

FIGURE Triplet 1 at one month

TABLE 1 Dermatoglyphic findings.

\begin{tabular}{llll}
\hline & & Fingertip patterns & Palmar formulae $^{*}$ \\
\hline Triplet 1 & Right & UL W UL UL UL & $11.9 .7 .5-t-0.0 .0 .0 . \mathrm{L}$. \\
& Left & UL W UL W UL & $11.9 .7 .4-t-0.0 .0 .0 . \mathrm{L}$. \\
Triplet 2 & Right & UL RL UL UL UL & $11.9 .7 .5-t-0.0 .0 .0 . \mathrm{L}$. \\
& Left & UL RL UL UL UL & $11.9 .7 .5-t-0.0 .0 .0 . \mathrm{L}$. \\
Triplet 3 & Right & UL RL UL UL UL & $11.9 .7 .5-t-0.0 .0 .0 . \mathrm{L}$. \\
& Left & UL RL UL UL UL & $11.9 .7 .5-t-0.0 .0 .0 . \mathrm{L}$. \\
\hline
\end{tabular}

* Main line terminations D.C.B.A., axial triradius position-pattern areas hypothenar. thenar/interdigital one $\left(1_{1}\right), 1_{2}, 1_{3}, 1_{4}$

evaluated, the total ridge count appeared higher in triplet 1 than in her brothers, resulting from the thinning of the width of the ridges.

\section{CYTOGENETIC STUDIES}

Lymphocyte cultures were set up on three different occasions and invariably revealed a homogeneous $46, X Y$ karyotype in all the triplets. Fibroblast cultures were derived from skin biopsies of the upper arm and showed a non-mosaic chromosome constitution of $45, \mathrm{X}$ in triplet 1 and $46, \mathrm{XY}$ in triplets 2 and 3 (table 2).

Lymphocyte cultures of the parents showed normal karyotypes. Differential banding with quinacrine showed identical chromosome markers in the
TABLE 2 Cytogenetic findings in the triplets and their parents.

\begin{tabular}{llll}
\hline Subject & Tissue & $\begin{array}{l}\text { No of cells } \\
\text { studied }\end{array}$ & Karyotype \\
\hline Triplet 1 & Blood & $120^{*}$ & $46 . \mathrm{XY}$ \\
& Skin & 38 & $45 . \mathrm{X}$ \\
Triplet 2 & Blood & $90^{*}$ & $46 . \mathrm{XY}$ \\
& Skin & 25 & $46 . \mathrm{XY}$ \\
Triplet 3 & Blood & $106^{*}$ & $46 . \mathrm{XY}$ \\
& Skin & 26 & $46 . \mathrm{XY}$ \\
Mother & Blood & 44 & $46 . \mathrm{XX}$ \\
Father & Blood & 51 & $46 . \mathrm{XY}$ \\
\hline
\end{tabular}

* Total of three separate cultures.

triplets and the $\mathrm{Y}$ chromosome resembled that of their father.

\section{ZYGOSITY STUDIES}

Zygosity determinations included genetic marker studies of red cell antigens, HLA typing, red cell enzymes, and serum proteins, all of which were identical.

The triplets were identical for the following RBC antigens: A, B, O,M,N,S, $\mathrm{P}_{1}, \mathrm{C}, \mathrm{c}, \mathrm{D}, \mathrm{e}, \mathrm{K}, \mathrm{k}, \mathrm{Fy}^{\mathrm{a}}, \mathrm{Fy}^{\mathrm{b}}, \mathrm{Jk}^{\mathrm{a}}$, $\mathrm{Jk}^{\mathrm{b}}, \mathrm{Le}^{\mathrm{a}}$, and $\mathrm{Le}^{\mathrm{b}}$. The HLA phenotype of the triplets was A1,A28,B35,B18,Cw4. They also had the same following RBC enzymes: adenosine deaminase, adenylate kinase, acid phosphatase, esterase $\mathrm{D}$, and phosphoglucomutase 1 . The following serum proteins were tested and found to be identical: gammaglobulin (IGG), group specific component $(\mathrm{Gc})$, transferrin (Tf), and haptoglobin $(\mathrm{Hp})$.

The probability of the triplets being $\mathrm{MZ}$ was estimated as being greater than $99 \%$.

\section{Discussion}

Monozygotic twins discordant for karyotype or phenotype or both are a notable, though extremely rare, exception to the concept of identity in the $M Z$ twin pair. Most available reports (table 3 ) refer to pairs of female $\mathrm{MZ}$ twins discordant for Turner's syndrome or gonadal dysgenesis. In all these observations, the $46, X X$ and the $45, X$ cell lines were detected in different proportions in the tissues examined in both twins. Only one apparent exception to this rule is known ${ }^{6}$ and concerned a pair of $\mathrm{MZ}$ twins with similar features and some degree of virilisation, which was more pronounced in one member of the pair. The female sex was assigned to both twins. However, twin 1 had bilateral streak ovaries and a 45,X karyotype, while twin 2 had ambiguous genitalia, a streak ovary on one side, an immature testis on the other side, and displayed a 


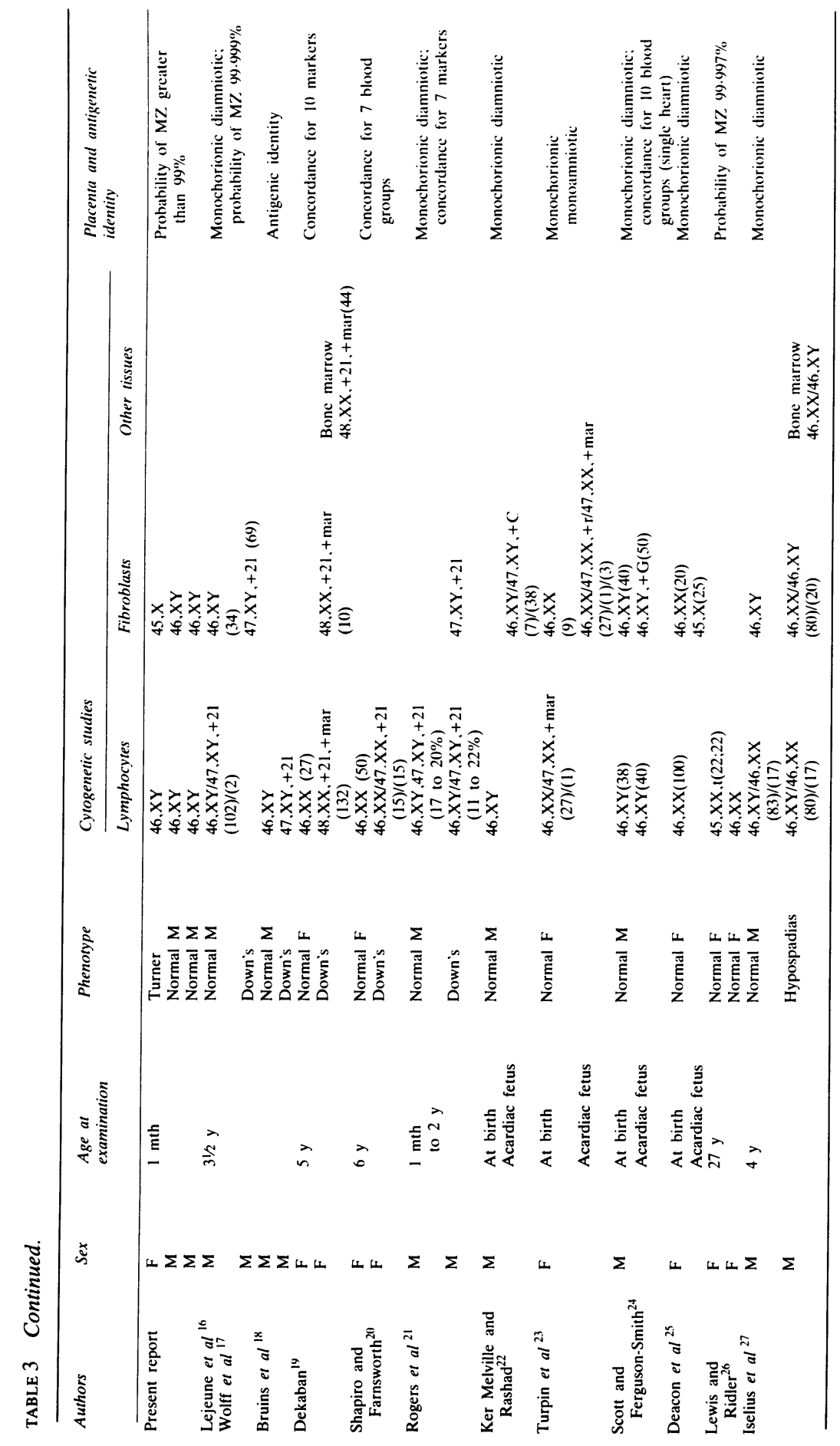


$45, \mathrm{X} / 46, \mathrm{XY}$ mosaicism. Two other incomplete reports concerned pairs of phenotypically female twins, one of whom had multiple malformations. ${ }^{9} 10$ In addition, Ross et $a l^{8}$ found an X/XXX complement in a phenotypically normal female twin and in her co-twin who had gonadal dysgenesis, while Aurias $^{12}$ described an isochromosome Xq mosaicism in the amenorrhoeic $\mathrm{MZ}$ twin sister of a normal $46, X X$ female.

Four sets of $\mathrm{MZ}$ twins discordant for phenotypic sex have been described previously. ${ }^{14}{ }^{14} 27$ In all of these instances one twin was phenotypically male, while the other had either Turner's syndrome or gonadal dysgenesis. The clinical observations were consistent with the cytogenetic findings in three cases. In the fourth case ${ }^{4}$ chromosome studies revealed a $45, X / 46, X Y$ karyotype in the female twin with signs of Turner's syndrome, while a 45,X chromosome complement was found in the phenotypically normal male co-twin. The authors assumed that a $45, \mathrm{X} / 46, \mathrm{XY}$ chromosome complement was present in both twins, though the $46, X Y$ line could not be demonstrated in the male.

Further examples of MZHT are shown by pairs either discordant for trisomy $21^{15} \quad 16 \quad 18-21$ or because one of them was a chromosomally abnormal acardiac fetus $^{13}$ 23-25 (table 3). All these cases, and in particular those in which not less than two different tissues were analysed, showed mosaic chromosome constitutions in one or both twins. Timing exactly the origin of the accident is difficult, but it is suggested that the error arose during an early postzygotic cell division. There are a few theoretical mechanisms to explain the different cytogenetic complements observed in all these MZHT. Chromosomal loss or mitotic non-disjunction could occur in a euploid cell of a pair of MZ twins. Alternatively, chromosomal loss could occur during an early division in a zygote with 47 chromosomes.

Two additional observations show possible examples of MZHT, although the mechanism of the origin of these unusual sets of twins is not fully understood. The first study ${ }^{26}$ concerned a $45, \mathrm{XX}, \mathrm{t}(22 ; 22)(\mathrm{p} 11 ; \mathrm{q} 11)$ or $45, \mathrm{XX}, \mathrm{i}(22 \mathrm{q})$ woman with a history of recurrent abortion. The healthy twin sister had a normal female complement, even though marker studies indicated that the twins were probably MZ. The simplest hypothesis accounting for these findings is a postzygotic mitotic origin of an isochromosome with mixoploid twinning. The second observation ${ }^{22}$ was an unusual $\mathrm{XX} / \mathrm{XY}$ chimaerism observed in identical twin boys, who had both $A_{1}$ and $B$ cells in their peripheral blood. Chimaerism in somatic tissues outside the blood cells was shown in only one of the twins. According to the authors, the most likely explanation for these findings was that the twins originated as an $\mathrm{A}_{1} 0 \stackrel{?}{\Rightarrow}$ zygote, which became monozygotic fetuses, and that an early B0,XX triplet embryo became attached to 0 and was absorbed by the embryo of twin 2 .

The present study reports the first example of $\frac{\bar{m}}{\square}$ discordant sex in one member of MZ triplets. The $\stackrel{\mathbb{Q}}{\Omega}$ presence of a $46, X Y$ karyotype in the circulating lymphocytes of these triplets suggests that the zygote itself from which they originated had a 46, XY constitution. Afterwards, twin 1 lost the $\mathrm{Y}$ chromosome in the majority of tissues, but it was $\stackrel{\omega}{\sigma}$ retained in the blood forming tissues. The general features of this subject, who has the full manifestations of Turner's syndrome, favour the idea of a very $N$ early origin of the mitotic error. The presence of the same marker chromosomes in the $\mathrm{X} 0$ and $\mathrm{XY}$ cell lines rules out the possibility that the $46, X Y$ cells found in the blood of twin 1 had originated from a $\vec{T}$ graft from her brothers' blood.

According to previous observations ${ }^{1428}$ one can predict that the presence of a $45, \mathrm{X}$ together with a $46, \mathrm{XY}$ cell line will favour a greater height in this patient compared to the average height reported for Turner's syndrome. Furthermore, X/XY chromo- of some mosaicism is often associated with mixed gonadal dysgenesis, which is characterised by the presence of a unilateral streak gonad and by a primitive testis on the opposite side. At present, no attempt has been made to assess the gonadal $\stackrel{\square}{\complement}$ histology and karyotype in our patient. This aspect $\overrightarrow{\vec{\rho}}$ will be evaluated in the future, particularly in view $\frac{0}{3}$ of the well established risk of cancer in gonads of $\mathrm{X} / \mathrm{XY}$ subjects. However, the close similarity of our observation with that of Schmidt et al ${ }^{14}$ suggests that the gonadal tissues of twin 1 could consist only of a homogeneous $45, X$ cell line.

We wish to thank Drs Mirella Mariani, Carla Bisdomini, Luisa Mottola, Aurora Sossi, and Anna $\frac{1}{3}$ Maria Guidi for genetic marker studies.

\section{References}

1 Turpin R, Lejeune J, Lafourcade J, Chigot PL, Salmon C. Presomption de monozygotisme en dépit d'un dimorphisme $N$ sexuel: sujet masculin XY et sujet neutre haplo X. CR Acad Sci [D] (Paris) 1961;252:2945-6.

2 Benirschke K, Driscole SG. The placenta in multiple pregnancy. Handbuch Pathol Histol 1967;7:187.

${ }^{3}$ Mikkelsen M, Frøland A, Ellebjerg J. X0/XX mosaicism in a pair of presumably monozygotic twins with different pheno- 6 types. Cytogenetics 1963;2:86-98.

4 Dent T, Edwards JH. Monozygotic twins of different sex. Proc $\mathbb{Q}$ $X I$ Int Congr Genet, Den Hague. Amsterdam: Excerpta Medica, 1963:304.

${ }^{5}$ Edwards JH, Dent T, Kahn J. Monozygotic twins of different sex. J Med Genet 1966;3:117-23.

${ }^{6}$ Russel A, Machos A, Butler CJ, Abraham JM. Gonadal dysgenesis and its unilateral variant with testis in monozygous twins: related discordance in sex chromosomal status. $J$ Clin Endocrinol 1966;26:1282-92. 
${ }^{7}$ Bourdy JJ. Contribution à l'étude du monozygotisme hétérocaryote. A propos d'un couple fille normale-syndrome de Turner. Thése pour le Doctorat en Médecine, Paris, 1969.

${ }^{8}$ Ross GT, Tjio JH, Lipsett MB. Cytogenetic studies of presumptively monozygotic twin girls discordant for gonadal dysgenesis $J$ Clin Endocrinol 1969:29:440-5.

${ }^{9}$ Benirschke K, Sullivan MM. Chromosomally discordant monozygous twins. Human Chromosome Newsletter 1965:15:3.

10 Shine IB, Corney G. Turner's syndrome in monozygotic twins. $J$ Med Genet 1966;3:124-8.

11 Potter AM. Taitz LS. Turner's syndrome in one of monozygotic twins with mosaicism. Acta Paediatr Scand 1972;61:473-6.

12 Aurias A. Contribution à l'étude du mécanisme et de la signification du monozygotisme hététocaryote. Thése pour le Doctorat en Médecine, Paris, 1974.

13 Karp L, Bryant J, Tagatz G, Giblett F. Fialkow PJ. The occurrence of gonadal dysgenesis in association with monozygotic twins. J Med Genet 1975;12:70-8.

${ }^{14}$ Schmidt R, Sobel EH, Nitowsky HM, Dar H, Allen FH. Monozygotic twins discordant for sex. J Med Genet 1976;13:64 79 .

15 Weiss E. Loevy H. Saunders A. Pruzansky S, Rosenthal IM. Monozygotic twins discordant for Ullrich-Turner syndrome. Am J Med Genet 1982;13:389-99.

${ }^{16}$ Lejeune J, Lafourcade J, Scharer K. et al. Monozygotisme hétérocaryote: jumeau normal et jumeau trisomique 21 . $C R$ Acad Sci [D] (Paris) 1962;254:4404-6.

17 Wolff E, Scharer K, Lejeune J. Contributions à l'étude des jumeaux mongoliens. Un cas de monozygotisme héterocaryote. Helv Paediatr Acta 1962;17:301-8.

18 Bruins JW, Van Bolhuis J, Bijlsma JB. Nijenshuisle LE. Discordant mongolism in monozygotic twins (1963). Quoted by Gilgenkrantz S, Marchal C, Wendremaire Ph, Seger M.
Cytogenetic and antigenic studies in a pair of twins: a normal boy and a trisomic 21 girl with chimera. In: Twin research. Vol. 3. Twin biology and multiple pregnancy. New York: Liss, 1981:141-53.

${ }^{19}$ Dekaban A. Twins probably monozygotic, one mongoloid with 48 chromosomes, the other normal. Cytogenetics 1965:4:228-39.

20) Shapiro LR. Farnsworth PG. Down`s syndrome in twins. Clin Genet 1972:3:363-70.

21 Rogers JG. Voullaire L, Gold H. Monozygotic twins discordant for trisomy 21. Am J Med Genet 1982:11:143-6.

22 Ker Melville G, Rashad NM. Autosomal trisomy in a discordant monozygotic twin. Nature 1966:212:727.

${ }^{23}$ Turpin R, Bocquet L. Grasset J. Etude d'un couple monozygote fille normale-montre acardiaque féminin. Ann Genet (Paris) 1967;10:107-13

${ }^{24}$ Scott JM, Ferguson-Smith MA. Heterokaryotypic monozygotic twins and the acardic monster. J Obstet Gynaecol Br Comm 1973;80:52-9.

${ }^{25}$ Deacon JS, Machin GA, Martin IME. Nicholson S. Swankwo DC, Wintemute IL. Investigation of acephalus. Am J Med Genet 1980;5:85-90.

${ }^{26}$ Lewis BV, Ridler AC. Recurrent abortion associated with 22:22 translocation, or isochromosome $22 \mathrm{q}$ in a monozygous twin. Hum Genet 1977:37:81-5.

${ }^{27}$ Iselius L, Lambert B, Lindsten J, Tippett P, Gavin J, Daniels G. Unusual XX/XY chimerism. Ann Hum Genet 1979;43:89-96.

${ }^{28}$ Davidoff F, Federman DD. Mixed gonadal dysgenesis. Pediatrics $1973 ; 52: 725-42$.

Correspondence and requests for reprints to Professor Bruno Dallapiccola, Cattedra di Genetica Umana, Università di Urbino, Via Saffi 2, 61029 Urbino, Italy. 